\title{
A COMPARISON OF POSTOPERATIVE HEARING GAIN IN DRY AND WET EAR TYMPANOPLASTY
}

\author{
Anil Gangwar1, Vaibhav Kuchhal2
}

${ }_{1}^{1}{ }^{\text {rd }}$ Year Post Graduate, Department of Otorhinolaryngology and Head and Neck Surgery, Government Medical College and Hospital, Haldwani, Nainital.

2Professor and HOD, Department of Otorhinolaryngology and Head and Neck Surgery, Government Medical College and Hospital, Haldwani, Nainital.

\section{ABSTRACT}

\section{OBJECTIVE}

To compare hearing gain in dry and wet tympanoplasty.

\section{MATERIALS AND METHODS}

A total of 100 ears were included in the study. Two groups were created with 50 ears in each group. All patients had mucosal chronic otitis media. One group had dry ear, another had wet ear at the time of surgery. Type 1 tympanoplasty was done in all the cases by a single surgeon. Hearing gain was calculated 3 months after surgery for both groups and compared.

\section{RESULTS}

Hearing improvement seen in 35 (70\%) cases in dry ear group and 38 (76\%) cases in wet ear group. Statistically, both comparisons were insignificant.

\section{CONCLUSION}

The success of tympanoplasty was not adversely affected by the presence of discharge at time of surgery and outcomes were comparable to those of the operation done for dry ear.

\section{KEYWORDS}

Tympanoplasty, Dry Ear, Wet Ear.

HOW TO CITE THIS ARTICLE: Gangwar A, Kuchhal V. A comparison of postoperative hearing gain in dry and wet ear tympanoplasty. J. Evolution Med. Dent. Sci. 2016;5(42):2614-2616, DOI: 10.14260/jemds/2016/611

\section{INTRODUCTION}

Chronic Otitis Media is an inflammatory process in the middle ear space. It can cause long term, more often permanent changes in tympanic membrane that includes atelectasis, dimer formation, perforation, tympanosclerosis, retraction pocket development or cholesteatoma. ${ }^{1}$ The patient may present with ear discharge, a permanent perforation or impairment in hearing. Usually most of the perforation heals spontaneously, but this spontaneous healing is affected by chronicity of infection and certain permanent changes in the margin of perforation leading to a non-healing permanent perforation. This leads to a constant exposure of middle ear for re-infection and hearing disability. ${ }^{2}$ COM is classified as inactive mucosal type, active mucosal type, inactive squamous type, active squamous type and healed type. ${ }^{1}$ Tympanoplasty refers to reconstruction of the tympanic membrane defect along with elimination of disease, if any, from the middle ear and reconstruction of ossicular chain if diseased. ${ }^{2}$ Goals of tympanoplasty are to achieve a dry ear by eradicating middle ear disease and hearing improvement by closure of any tympanic membrane perforation by grafting and/or ossicular reconstruction. ${ }^{1}$ The discharging ear presents to the surgeon whether to operate or not to operate.

Financial or Other, Competing Interest: None.

Submission 11-03-2016, Peer Review 13-04-2016,

Acceptance 19-04-2016, Published 26-05-2016.

Corresponding Author:

Dr. Anil Gangwar,

$3^{\text {rd }}$ Year Post Graduate,

Room No. 89, New SR Hostel,

Government Medical College,

Haldwani, Nainital.

Uttarakhand.

E-mail: kanmananil@gmail.com

DOI: $10.14260 /$ jemds $/ 2016 / 611$
This is due to the widespread belief that the success rate while doing tympanoplasty on wet ear is decidedly inferior. The main objective of this study is to find the effect of this discharge from the ear on the success of tympanoplasty. ${ }^{3}$ This study has been conducted to compare the outcomes of type 1 tympanoplasty in dry and wet ears.

\section{MATERIAL AND METHOD}

The study was conducted on patients of age 10 years to 60 years and of either sex presenting with Chronic Otitis Media in OPD of Otorhinolaryngology in Government Medical College and Dr. Sushila Tiwari Hospital, Haldwani. The study period was November 2013 to November 2015. This was a prospective study, which was conducted in Department of Otorhinolaryngology after taking duly permission from the Institutional Ethical Committee. The minimum sample size in this study was 100 cases with 50 patients each in dry and wet ear group. Due written informed consent was obtained from the patients before the recruitment. The consent was explained in vernacular language to the patients.

Patients of age less than 10 and above 60 years with squamous type chronic otitis media, culture positive discharge to pathogen, any active predisposing sinonasal pathology, complicated COM, Eustachian tube dysfunction, totally deaf ear, syndromal deafness, patients who refuse or unfit for surgery, SNHL and mixed hearing loss and patients with revision surgery were excluded. The patients were subjected to clinical, audiological, radiological and laboratory investigations according to the proforma. Type 1 Tympanoplasty was done by a single surgeon through the post-aural approach using the underlay technique and utilising temporalis fascia graft in all patients. Postoperatively, patients were given antihistamines for 3 weeks 
and antibiotics, analgesics, topical nasal decongestants were used for 1 week.

The mastoid dressing was removed after 48 hours of surgery and the sutures were removed after 1 week of surgery and regular follow-up took place at 3rd week, 6th week and $12^{\text {th }}$ week postoperatively. Hearing improvement was evaluated with the help of pure tone audiometry at 3rd month and compared with preoperative pure tone audiometry. The hearing gain was evaluated in speech frequency of $0.5,1$ and 2 $\mathrm{KHz}$. The results were tabulated and statistical analysis was done. Outcomes were compared in terms of postoperative hearing improvement. All the data was filled in Microsoft Excel (Office 2010), which was then transferred to SPSS version 21, for statistical analysis. Differences in the values of preoperative and postoperative clinical and laboratory outcome variables in the study groups were evaluated using Chi-square test. For this study the confidence interval percentage was $95 \%$ and result was considered significant if the P-value was less than 0.05 .

\section{RESULTS}

In our study, hearing improvement seen in 35 (70\%) cases and worsening in $3(6 \%)$ cases in dry ear group; 38 (76\%) cases showed hearing improvement and $3(6 \%)$ cases showed worsening in wet ear group (Table 1).

\begin{tabular}{|c|c|c|c|c|}
\hline $\begin{array}{c}\text { Hearing } \\
\text { Gain after } \\
\text { Surgery } \\
\text { (dB gain) }\end{array}$ & $\begin{array}{c}\text { Dry } \\
\text { Ear } \\
\text { (n) }\end{array}$ & $\begin{array}{c}\text { Percentage } \\
\text { (\%) }\end{array}$ & $\begin{array}{c}\text { Wet } \\
\text { Ear } \\
\text { (n) }\end{array}$ & $\begin{array}{c}\text { Percentage } \\
\text { (\%) }\end{array}$ \\
\hline No gain & 12 & 24 & 9 & 18 \\
\hline$\leq 5$ & 8 & 16 & 3 & 6 \\
\hline $6-10$ & 9 & 18 & 16 & 32 \\
\hline$>10$ & 18 & 36 & 19 & 38 \\
\hline Worsened & 3 & 6 & 3 & 6 \\
\hline \multicolumn{5}{|c}{ Table 1: Hearing Gain } \\
\hline
\end{tabular}

$$
\chi^{2}=4.688, p=0.312
$$

\begin{tabular}{|c|c|c|c|c|}
\hline $\begin{array}{c}\text { Graft } \\
\text { Uptake }\end{array}$ & $\begin{array}{c}\text { Dry } \\
\text { Ear } \\
\text { (n) }\end{array}$ & $\begin{array}{c}\text { Percentage } \\
\text { (\%) }\end{array}$ & $\begin{array}{c}\text { Wet } \\
\text { Ear } \\
\text { (n) }\end{array}$ & $\begin{array}{c}\text { Percentage } \\
\text { (\%) }\end{array}$ \\
\hline Not taken & 4 & 8 & 5 & 10 \\
\hline \multicolumn{4}{|c|}{ Table 2: Graft Failure } \\
\hline
\end{tabular}

\section{DISCUSSION}

It is a common belief that tympanoplasty should be done in a totally dry ear to attain a successful result. The doubt about the effect of wetness of the middle ear on the result of tympanoplasty, encouraged us to study and compare it with those of dry ear. It is difficult to control all variables that play a part in determining the outcome of tympanoplasty. The approach, graft material, technique and surgeon for both groups were same, so we consider that both groups are broadly comparable.

In our study, hearing improvement was noted in 35 (70\%) patients in dry ear group and $38(76 \%)$ patients in wet ear and $19(38 \%)$ and $18(36 \%)$ patients had hearing improvement of more than $10 \mathrm{~dB}$ in wet ear groups and dry ear group respectively; $6 \%$ cases in both groups showed worsening of hearing as there was graft failure in 4 cases $(8 \%)$ in dry ear group and 5 cases (10\%) in wet ear group (Table 2 ). There was no statistical significance $(\mathrm{p}=0.312$ ) found on comparing both groups with respect to hearing improvement. In a study conducted by Sameh Hosny et al, hearing gain rate of $91.3 \%$ in wet ears and $92.3 \%$ in dry ears was seen and these differences were not statistically significant. ${ }^{4}$ Hatice Emir et al found that post-operative hearing gain was $47.3 \%$ in dry ears and $40.7 \%$ in wet ears. ${ }^{5}$ Benjamin D et al found post-operative hearing gain for dry and wet ear were not statistically significant. 6 Tos M observed more than $10 \mathrm{~dB}$ hearing gain in $87 \%$ in dry ears and $66 \%$ in wet ear group. ${ }^{7}$

Raj et al observed improvement in hearings in $68 \%$ of the patients undergone myringoplasty in wet ear. ${ }^{8}$ Blakley et al found that in ears with persistent infection, the hearing outcome after tympanomastoidectomy surgery depended more on pre-operative hearing level than on the type of tympanoplasty performed. ${ }^{9}$ Anita Krishnan et al observed postoperative air-bone gap of less than $20 \mathrm{~dB}$ is in $75 \%$ of cases with quiescent ear and $80 \%$ of cases with dry ears who underwent tympanomastoidectomy. ${ }^{10}$ Eero Vartianen et al observed that the pre-operative ear status whether dry or wet did not significantly affect the improvement of mean air-bone gap. ${ }^{11}$

\section{CONCLUSION}

Postoperative hearing gain was $0-5 \mathrm{~dB}$ in 8 patients with dry ear and 3 patients with wet ear, 6-10 dB hearing gain in 8 patients with dry ear and 16 patients with wet ear. There was more than $10 \mathrm{~dB}$ hearing gain in 19 patients with dry ear as well as 19 patients with wet ear. Statistically, p-value is 0.312 ( $p>0.05$ ) which is insignificant. The very fact that the $p$-value is insignificant in both groups for hearing improvement, so the presence of sterile discharge in the ear at the time of surgery has no impact on postoperative hearing gain. There was graft failure in 4 cases (8\%) in dry ear group and 5 cases $(10 \%)$ in wet ear group. This accounted for worsened hearing in $6 \%$ cases in both the groups. No other complications were seen in patients during follow-up.

\section{LIMITATIONS}

\section{The Present Study has following Limitations}

1. The findings cannot be generalized as

- The study has limited number of cases.

- The study was conducted in a particular area.

2. There was difficulty in getting long-term follow-up of patients.

3. Failure rate might have increased due to poor hygiene of the patients, as most of them were of low socio-economic status.

4. Confounding factors like atopy, immunological factors, etc. can also interfere with the results.

\section{REFERENCES}

1. Gopen Q. Pathology and clinical course of the inflammatory diseases of the middle ear. In Aina Julianna Gulya, Glasscock-Shambaugh, Surgery of the ear, Philadelphia, Saunders WB Co. Chapter-25, 2010; $6^{\text {th }}$ ed:p 425.

2. Ravishankar C, Dhanapala N, Rajput R. A review of results of type I tympanoplasty in active and inactive tubotympanic chronic suppurative otitis media. Research in Otolaryngology 2014,3(5):77-80. DOI:10.5923/j.otolaryn.20140305. 
3. Nagle SK, Jagade MV, Gandhi SR, et al. Comparative study of outcome of type 1 tympanoplasty in dry and wet ear. Indian J Otolaryngol Head Neck Surg 2009;61(2):138-40.

4. Sameh Hosny, Mohammad Waheed El-Anwar, Mohammad Abd-Elhady, et al. Outcomes of myringoplasty in wet and dry ears. Int Adv Otol 2014;10(3):256-9.

DOI: $10.5152 /$ iao.2014.500.

5. Emin H, Ceylan K, Kizilkaya Z, et al. Success is a matter of experience: type 1 tympanoplasty. Eur Arc Otorhinolarygol 2007;264(6):595-9.

6. Benjamin D Webb, Chang CY. Efficacy of tympanoplasty without mastoidectomy for chronic suppurative otitis media. Archotolaryngol Head and Neck Surg 2008;134(11):1155-8.
7. Tos M. Results of tympanoplasty. Acta otolaryngol 1973;75(2-6):286-7.

8. Raj A. Review of patients undergoing wet myringoplasty. Indian J Otology 1999;5(3):134-6.

9. Blakley BW, Kim S, VanCamp M. Preoperative hearing predicts postoperative hearing. Otolaryngol Head Neck Surg 1998;119(6):559-63.

10. Anita Krishnan, Reddy EK, Chandrakiran C, et al. Tympanoplasty with and without cortical mastoidectomy-a comparative study. Indian J Otolaryngol Head Neck Surg 2002;54(3):195-8.

11. Vartainen E, Kärjä J, Karjalainen $S$, et al. Failures in myringoplasty. Arch Otolaryngol 1985;242(1):27-33. 